\title{
Impairments: Materiality and Fiscal Impact on Cape Verde' Major Contributors
}

\author{
Nuno Teixeira*, Maria José Lopes, Teresa Godinho \\ Department of Accounting and Finance, Business School of Setúbal, Setúbal, Portugal \\ Email address: \\ nuno.teixeira@esce.ips.pt (N. Teixeira), MJLopes28@hotmail.com (M. J. Lopes), teresa.godinho@esce.ips.pt (T. Godinho) \\ *Corresponding author
}

\section{To cite this article:}

Nuno Teixeira, Maria José Lopes, Teresa Godinho. Impairments: Materiality and Fiscal Impact on Cape Verde' Major Contributors. International Journal of Accounting, Finance and Risk Management. Vol. 4, No. 3, 2019, pp. 84-94. doi: 10.11648/j.ijafrm.20190403.12

Received: June 14, 2019; Accepted: July 16, 2019; Published: August 6, 2019

\begin{abstract}
This study aims to evaluate the material level of impairment losses registered by the Cape Verdean companies, as well as to analyze its fiscal impact. For this purpose, we ran the Cape Verdean' accounting standards about this subject and studied the tax procedures on impairment registration in the country. In the empirical study, we performed an analysis of the annual report and accounts for 2012 and 2011 of fifty-seven large companies in Cape Verde. These were the benchmark years for establishing the country's major contributors and the normative framework on impairment' application. Evidences showed that, in its vast majority, companies registered impairment losses, namely on customer debts and inventories. We also found that, empirically, impairment value was materially relevant and had impact on tax level, giving the meaningful association between payed taxes (negative association) and turnover (positive association), and registered impairment. In a future work, already in progress, we intended to verify the impairment registration' during the period between 2013 and 2016. We will also try to understand if there is a greater social responsibility by Cape Verde' major contributors.
\end{abstract}

Keywords: Impairment, Tax Management, Accounting Standards

\section{Introduction}

Nowadays, several countries are attempting an effort to adopt the International Accounting Standards issued by IASB - International Accounting Standards Board, in order to ensure credibility in its accounting information and, also, international acceptance [1]. Cape Verde is not oblivious to this process, due to several factors, such economy liberalization, new external investors, its association with most developed countries, and the internationalization of its companies. The country brought its accounting system closer to the international normative, by creating the Accounting and Financial Reporting Standardization System - Sistema de Normalização Contabilística e de Relato Financeiro (SNCRF), by [2], which replaced the National Accounting Plan (PNC), approved by the Decree $n^{\circ} 4 / 84$, from January the $30^{\text {th }}, 1984$.

This paradigm change introduced in Cape Verde accounting and taxation, justifies, by itself, the significance of this theme, being, currently, one of the most discussed issues in the country, either by financial institutions as by professionals.

Impairment of assets was originated in the draft presentation of Exposure Draft E55 - Impairment of Asset, dated May 1997. According to Cunha, Correia and Oliveira [3], the impairment is the reduction of the recoverable value of an asset, adjusting its value to its real economic return capacity, underpinning the application of the accounting principle of prudence. In this way, impairment translates a loss of value suffered by an asset for external or internal reasons to the economic entity, translating a lower capacity that the asset has to create benefits. Thus, this accounting concept is strongly influenced by the qualitative characteristic of prudence, since this is a decisive aspect to obtain the reliability of the amounts recorded in the assets of the financial statements. However, its registration implies an increase in the costs of the activity, without a counterpart of financial outflows, which can lead to an abusive reduction of economic results and taxes to be delivered to the state.

Thus, the concept of impairment and the objective of its registration in the financial statements of the companies has 
generated some reflection in the regulatory entities and tax authorities and in the professionals and academics of the financial area.

Also, the scarcity of researches, in this area, in Cape Verde, has motivated the choice of the theme, that it is expeted to be timely and of capital importance for companies, tax authorities and academics in general.

In this sense, the purpose of the present work is to study the material level of impairment losses registered by the Cape Verdean companies, as well as to analyze its fiscal impact. To do so, we developed an empirical study, using as sample the eighty major contributors list defined by the Finance Ministry. We randomly selected fifty-seven large companies from that list, and we analysed their Annual Report \& Accounts from 2011 and 2012, because those were the reference years for the establishment of the major contributors, as well as for the accounting normative. It is noteworthy that, after a first analysis of the financial statements, we found that more than $90 \%$ of the impairment losses that have been registered, related to customer debts and inventories. Being so, these are the two categories of impairment that represent the focus of the empirical study we perform. To evidence the material level of impairment recorded in net income and assets, we performed tests of averages differences between the values of these headings, with and without impairment losses. Regarding the tax impact, we accomplished multivariate linear regression models.

The work is divided into three parts. The first part presents a literature review, where we also contextualize the accounting standardization process at national level and discuss basic concepts about impairment, including its tax framework.

The second part of the work is the empirical study. We identify the purpose in more detail, define the methodology and the statistical variables and techniques used in the research. In addition, we analyse and discuss the obtained results.

Finally, in the third part, we present the overall conclusions of the developed work, as well as some research limitations and future research suggestions.

\section{Theoretical Framework}

\subsection{The Accounting Concept of Impairment Losses}

Impairment losses have become part of the accounting vocabulary of Cape Verdean companies, from the $1^{\text {st }}$ of January 2009, arising from the entry into force of the Accounting Standardization and Financial Reporting System (SNCRF), being the term unknown in the country's normative until that day.

Impairment losses are treated by two Standards, depending on the nature of the assets:

a) NRF 17 - Impairment of Assets, which is about nonfinancial assets;

b) NRF 16 - Financial instruments, which deals with financial assets.

Specifically, Impairment of assets is also mentioned in the precepts of the following Standards: NRF 6 - Intangible assets; NRF 7 - Tangible fixed assets; NRF 8 - Non-current assets held for sale and discontinued operating units; NRF 10 - Investment properties; NRF 12 - Agriculture; NRF 13 Inventories; RF 23 - Interests in joint ventures and investments in associates.

Either the international standards, as the Cape Verdean national standards about impairment, establish that mostly every asset, despite being financial or non-financial, might be subject to impairment procedures, with specific variations considered. First-time impairment tests and impairment reversals are part of each set of standards.

This happens because there is, almost always, a chance that book value becomes different from recoverable value, over time. Therefore, at the end of each accounting period, both values must be calculated and compared with one another, to collect evidences that show if there is impairment, or not.

As far as the Cape Verdean national standards are concerned, impairment procedures referred on NRF $6-$ Intangible assets (§111) and on NRF 7 - Tangible fixed assets ( $\$ 63)$ both refer NRF 17 - Impairment of Assets.

Thus, considering that the assets object to this research (debts and inventories) are predicted on NRF 16 - Financial instruments and on NRF 17 - Impairment of Assets, and in the case of inventories also on NRF 13 - Inventories, we will centre our study on these.

NRF 17 comprises objective, scope, key definitions, recognition, measurement, presentation and disclosure.

Accordingly, $\$ 1$ explain procedures that must applied to ensure that the entity's assets are carried at no more than their recoverable amount. Whenever an asset is carried at a higher value than its recoverable amount, it is impaired, and the standard requires the recognition of impairment loss. Any impairment loss is recognised as an expense in profit or loss for assets carried at cost.

So, the standard requires an entity to assess, at each reporting date, whether there are any indicators that assets may be impaired and sets out the requirements to account for and report impairment of most nonfinancial assets. The standard also deals with impairment testing for all tangible and intangible assets, except for assets that are covered by other standard.

Extensive disclosure is required $(\$ \S 61$ to 65$)$ for the impairment test and any impairment loss recognised. For each class of assets, the entity must disclose:

a) the amounts of impairments recognised / reversed on Profit \& Loss Account and directly on Equity;

b) if there was recognition on Profit \& Loss Account, the identification of the account;

c) if applicable, segment information;

d) impairment tests performed and impairments recognised. 
Financial instruments are contracts that origin both a financial asset on an entity and a financial liability or equity instrument in another entity [4]. To exemplify, the author refers receivables, debts, equity instruments and financial loans.

Thus, NRF 16, in addition to defining the accounting treatment of financial instruments and proper presentation and disclosure requirements, also recommends the treatment for impaired financial assets, on the following paragraphs: impairment ( $\S \S 23$ to 29 ); recognition ( $\S \S 23$ to 26); measurement ( $\S 27)$; reversal ( $\S 28$ and 29).

As for the procedures, they are the same as NRF 17. At each reporting date, all entities must assess all financial assets' impairment, if these are measured at other than fair value, in Profit \& Loss Account.

If there is objective evidence of impairment, the entity must recognize an impairment loss in Profit \& Loss Account. The standard also suggests potential situations of impairment, such as:

a) Financial difficulty of the debtor;

b) Contractual breach, such as non-payment or failure to pay the debt;

c) Creditor, who for economic or legal reasons related to the financial difficulty of the debtor, offers concessions that the creditor would otherwise not consider;

d) Debtor's probable bankruptcy;

e) The disappearance of a market for financial assets due to debtor's financial difficulties;

f) Observable information indicating that there is a measurement' decrease of future estimable cash flows of a group of financial assets, since its initial recognition.

In both standards (17 and 16) is referred that, if, subsequently, the amount of impairment loss decreases, and such a decrease may be objectively related to an event occurring after recognition of impairment (such as an improvement in the debtor's risk rating) the entity must reverse the previously recognized impairment.

The SNCRF of Cape Verde establishes that the recognition of impairment losses in inventories must follow NRF $13-$ Inventories' guidelines. This is a specific standard, that defines accounting treatment for inventories and stresses that these should be measured by the lowest among net realizable value or cost. Net realizable value refers to the amount that an entity expects to carry out by selling the inventory in the ordinary course of the business activity, less the estimated cost of completion and the estimated costs necessary to make the sale

The cost of inventories will include costs of purchase (including taxes, transport, and handling) net of trade discounts received; costs of conversion (including fixed and variable manufacturing overheads) and other costs incurred in bringing the inventories to their present location and condition (less discounts, reductions and other similar items).

Whenever the recoverable amount of an inventory is less than its carrying amount, the entity must reduce the last, to the net realizable value, which is consistent with the principle that assets shall not be carried over at sums exceeding those which would be expected to result from their sale or use (impairment concept).

In Cape Verde, according to Gonçalves and Fernandes [5] adjustments to inventories will be directly recorded in its accounts (direct method).

It is noteworthy that NRF 13 at any time uses the expression "impairment", but, with the same meaning, it uses the expression "adjustment" to designate the difference between the cost of acquisition or production and the net realisable value of inventories.

\subsection{Impairment and Taxation}

Impairment, for being estimated losses, have a strong accounting normative discipline. Nevertheless, it involves subtle issues in the tax context [6], what stresses the need for a greater relationship between accounting and taxation.

In tax terms, impairment losses, in Cape Verde, are ruled by Tax Law, namely the Tax Law on Corporate Income CIRPC (Código de Imposto Sobre Rendimentos Das Pessoas Coletivas) and are accepted as losses, provided their compliance with the precepts of articles 39, 40, 41 and 42.

Only the following impairment losses are consider as taxdeductible:

a. Those related to coverage of doubtful receivables, calculated according to the sum of the credits on customers and resulting from the company's ordinary activity, at the end of the accounting period;

b. Those intended to cover inventories' value losses;

c. Those which have been constituted in harmony with the discipline imposed by the Insurance Institute to companies subject to their supervision.

Article 52 of the CIRPC also refers to the possibility of fiscal impairment acceptance on non-current assets, if they arise from duly substantiated abnormal causes, namely disasters, natural phenomena, exceptionally rapid technical innovations or significant changes and with adverse effect from the legal context.

In terms of impairment cost limits accepted, article 40 lays down that inventories' impairment losses cannot exceed the difference between their acquisition or production cost and their net realizable value. As regards impairment loss related to doubtful debts, the following situations are fiscally considered: the debtor is waiting for execution or bankruptcy proceedings; debts have been judicially claimed; debts have been overdue for more than six months and there is evidence that diligence has been made for their receipt.

Generically speaking, fiscally accepted impairments relate to losses associated to inventories and doubtful debts. Although article 52 Refer the possibility of impairments acceptance when it derives from non-current assets' exceptional devaluations, the law stresses that taxpayer should prove its existence through an exhibition to the Tax Authority (Direção Geral das Contribuições e Impostos DGCI) requesting authorisation. 


\subsection{Studies Analyzed About the Importance of Impairments}

Since impairment is a broad topic, covering almost all assets, the subject already has some studies done in several countries, although most of the works found, are related to the impairment of fixed or intangible goodwill.

Rodrigues [7], carried out a study on asset impairment in Cape Verde - NRF 17, with the objective of contributing to the knowledge and practical application of this concept. The research was based on the case study (impairment test for the customer portfolio) applied to a company whose activity was the sale and rental of automobiles. From the study, it was concluded that the accumulated impairment value was significantly higher than the total amount of the impairment, which was accepted by the tax authority of Cape Verde. It also concluded that it would sometimes be very difficult to ascertain whether there was impairment of goodwill since the acquired business was integrated into other areas.

Lucena, Fernandes, França e Capelleto [8] studied the level of disclosure of impairment of assets of the twelve largest banks in Brazil in 2007 and 2008. For this purpose, they analyzed the contents of the notes of the financial statements. The results showed similarity among the twelve banks regarding the lack of information for applying the impairment test. In 11 banks, there were indications of the existence of assets (financial and non-financial) valued higher than the financial recovery value, with the exception of one that stated to contemplate procedures for evaluating its assets. Nevertheless, the efforts of some banks were evidenced to show impairments in their explanatory notes.

Fernandes [9] also carried out a study on impairment in tangible fixed assets, having as objective to analyze how companies listed in PSI 20 (indicator of the evolution of the financial market in Portugal) in the period from 2006 to 2010 deal with this type of impairment. From this study, it was concluded that the accounts report referred to impairments in the explanatory notes. However, in some cases it was not possible to know the reasons why impairments occurred, since their value was included in depreciation. Moreover, the amounts of impairment losses were not justified in most cases.

Rafael [10] investigated the impairment of fixed assets of 10 Portuguese companies in 2010 and 2009, highlighting their accounting and tax aspects. It analyzed the impact of impairments and reversals of tangible fixed assets recorded and the information disclosed in the annex. The study revealed that recognition of the impairment loss on tangible fixed assets could cause significant changes in the value of non-current assets, net income, equity and income taxes payable. At the same time, the study has shown that the disclosures in the annex of financial statements do not always meet the requirements of the legislation and are incomplete and unintelligible in several companies.

Muhammad [11] investigated the effect of asset impairment on improving the quality of accounting information in Jordan. The study had a dual purpose: to verify to what extent its application could affect the decisions of the users of the financial information; to find out whether impairment was considered as a tool for increasing the credibility of accounting information or a tool for manipulation. The study was conducted in 2011 and the methodology used was based on the quantitative and qualitative approach to data collection: questionnaires and semi-structured interviews with financial professionals and academics to explore the motivations and techniques for recording asset impairment. Through the work carried out, it was concluded that, from the perspective of financial information users, asset impairment had a positive impact on the quality of accounting information, since impairments provided new information to the market and helped users in decision making. However, both practitioners and academics understood that misapplication of this standard could be a tool for manipulating financial information.

Carvalho, Rodrigues e Ferreira [12] studied the impairment losses of goodwill in the eight years of application of IAS / IFRS in Portugal, during the period from 2005 to 2012, in order to analyze their relevance in Portuguese companies with listed stock prices at Euronext Lisbon and to assess whether the economic crisis (started in 2008) has increased the recording of those losses. The methodology used was qualitative, based on the content analysis of the consolidated reports and accounts of the sample companies, which implied the analysis of quantitative and narrative information of 294 annual reports. The results of the study show that the financial crisis did not imply a significant increase in the value of impairment losses. In view of this, they concluded that in Portugal the decision to recognize impairment losses could be motivated, not only by economic and financial factors, but also by management interests. Of the companies that made up the study, those in the financial sector recorded more impairment losses. In addition, the study found that the most profitable companies tend to recognize less impairment losses.

Laskaridou and Athanasis [13] studied 26 companies in the food and beverage sectors listed on the Greek stock market and analyzed the impact of the new requirements of IAS 36 on the level of the impairment record, the accounting process and the disclosure of management and financial information. In their work, they attempted to understand whether impairment was more closely linked to the need to adequately inform the financial market about the real economic and financial situation of the companies or whether, on the other hand, it was intended to match management expectations on the level of results to spread. They found that the impairment record was related to tax management and the results that the companies intended to report.

Sooriyakumaran and Velnampy [14] studied the 5-year (2008 - 2012) reports and accounts of listed companies in the Sri Lankan financial market in order to observe the impact of the entry into force of IAS 36 in the impairment record and the form how companies disclose this information. The results showed that more than $90 \%$ of the analyzed 
companies did not comply with the disclosure procedures, not indicating the origin of such devaluations of the assets. In addition, they found that the impairment measurement was materially relevant and that it affected the results of the companies (especially those with negative results). Thus, they showed that the impairment record decreased the earnings per share in most of the companies analyzed.

Arachi and Bucci [15] analyzed panel data of about 7,000 Italian companies, with the purpose of verifying whether the impairment record was associated with the tax management of income taxes payable to the state. They analyzed the evolution of the financial statements from 1997 to 2006 to include the effect of the legislative changes that have occurred over the years in the Italian tax law. The econometric analysis made it possible to verify that the impairment record was associated with the level of tax rates practiced.

Edwards [16] surveyed 1,375 American companies that disclosed financial information from 1993 to 2015 and noted that impairment was a relevant indicator to signal the loss of financial capacity in the future of companies as their disclosure was normally associated with a future decrease in rating and an increase in financial risk.

Gunn, Khurana and Stein [17] studied the quarterly reports and accounts of about 3,000 US companies during the years 2007 to 2010 and showed that companies reporting more accurately in the pre-crisis years, recording more assiduously impairments as a way of presenting the assets at their most correct value, were also those that presented impairments more consistently during the years of financial crisis (from 2007 to 2009). In the remaining companies, there was a delay in the recording of impairments, as a way to avoid transmitting bad news. These conclusions also allowed us to show that it were the companies with a more systematized corporate governance, with more specialized auditors in the activity sector and with a higher level of indebtedness, who presented a greater care in the registry of asset impairments, highlighting the important role of existence of control mechanisms. Therefore, it was also these companies that presented greater capacity of financing.

Gordon and Hsu [18] studied the relationship between impairments recorded in non-current assets and future cashflows of companies. They analyzed data from about 5,400 companies in 26 countries that in some cases used IFRS and in other US GAAP standards. They found that the impairments recorded under IFRS had a negative relation to changes in future cash flows. As such, they had no great power to explain the future evolution of assets. Thus, their registration could also be due to fiscal concerns. On the other hand, they found that companies that used US GAAP, due to specific recognition and measurement procedures, usually recorded impairments with some delay.

Stein [19] also found in a sample of about 3,000 American companies, that those with more specialized auditors in the industries where companies have business, were more likely to disclose impairments and record higher values under these account headings. Thus, it was highlighted the importance of the auditor's knowledge to perform more rigorous financial information disclosure.

Thus, after analyzing the abovementioned studies on asset impairment, we can conclude that it is an important subject of accounting and taxation, since in addition to the need to comply with the regulations (this is even more relevant since they are in mostly cases just potential values), it has implications for the value of income taxes, and may lead to misuse of the registration of these items in the financial statements. In addition, it is found that the procedures for their disclosure are not always complied with. As such, we deem it to be a relevant topic to be addressed in a research paper.

\section{Empirical Study}

At this point we begin by characterize Cape Verde business sector, which represents the target population of our study. Following, we present the purposes and hypotheses of research, as well as methodology, in greater detail, and we describe the sample that we have used and the statistical techniques that we have applied. Lastly, we perform the analysis and discussion of the obtained results.

\subsection{Cape Verdean Business Sector' Characterization}

In terms of business units, the result of the IV Corporate Census carried out in 2012, produced by the National Institute of Statistics of Cape Verde, (Instituto Nacional de Estatística - INE) points to the existence of 9,736 active companies that year, including public and private entities. Compared to 2007 (year of the III Census) there are about 2,224 more companies, employing about 51,411 people (4,844 people more than in the same period of 2007) and generating a turnover of $250,821,807$ Thousand CVE - Cabo Verde Escudo (59,536,954 thousand CVE more than in the previous economic census).

Thus, the country had a very positive evolution in the African context, with regard to economic growth and social progress, with GDP growing on average in the order of $4 \%$ per year until 2013.

The sector that contributed the most to the positive evolution of GDP over the years was that of the services, whose GDP weight has stabilized by about $49 \%$, constituting, thus, the country's main productive base. According to the World Bank [20], in this sector, the largest contribution is from tourism that represents, on average, $21 \%$ of GDP, considered by the Government as one of the development leverages. The construction and trade sectors, which together represent about $24 \%$ of GDP, dependent very much on tourism' evolution, particularly, on the implementation of new hotels and on periodic flows of tourists on the various islands.

As for social indicators, it stands out the growth of GDP per capita, from 218,000 escudos in 2007 to 320,000 escudos in 2013, and the increase in the number of Companies that also originated a growth of jobs (from 2007 to 2012, the last analysed year, there was an increase of 2,224 Companies and 
4,844 jobs).

\subsection{Purposes of the Study}

Being impairment such an important topic, as it of links accounting standards with tax imperatives, several research projects have been developed over the years. For example, the results of the studies mentioned above, evidence that, beyond the need to comply with standards, impairments have implications on the value of income taxes and may lead to misuse on its registration, in the financial statements. In addition, it is found that the procedures for their disclosure are not always complied with.

Thus, what is proposed with this empirical study is to know the level of materiality of the registration of losses by the Cape Verdean companies and analyze their tax impact. To achieve this, the following specific objectives were established:

a) To identify the kind of impairment evidenced by Cape Verdean companies and to verify their impact on net income, as well as on assets;

b) To analyze the extent to which the registration of impairment losses may be used by Cape Verdean companies to reduce tax on profits.

Considering the proposed objects, we intended to respond two research hypotheses that have been defined:

$\mathrm{H} 1$ : Impairment value is materially relevant and has impact on net income value and on assets value of Cape Verdean companies.

$\mathrm{H} 2$ : Impairment value has an impact on income tax value of Cape Verdean companies.

\subsection{Research Method}

\subsubsection{Research Sample}

The Ministry of Finance and Planning of Cape Verde (MFP), in order to carry out a permanent and specialised monitoring of the companies that contributed the most to the economy, has decided to section it, as taxpayers, to distinct major contributors. Thus, the Government through Portaria No. 55/2013 of 14 December [21], stipulated the criteria for entities' selection. According to its article 2, active companies are to be chosen, if they meet at least one of the three criteria:

a) Business Volume higher than 200 million CVE;

b) Overall Tax value higher than 15 million CVE;

c) High level of associated risk determined from an application of specially designed software.

From the selection made, 80 large companies have emerged, which in tax terms are designated as major taxpayers. This list was published in the Official Boletim No. 13 December 2013, series II.

Thus, considering the Cape Verdean economy' casualness, and the strain in obtaining overview economic and financial data in the country, the chosen sample focus on the eighty companies considered to be major contributors, since they periodically carry out and fulfil their tax obligations. In addition, as far as large contributors are concerned, there is a single department (Major Contributors Department Repartição de Finanças dos Grandes Contribuintes), where Reports \& Accounts and other tax and legal obligations are carried, making data acquisition easier. Other taxpayers deliver Report \& Accounts in one of the other sixteen departments (Repartição de Finanças) according to each taxpayer's headquarter. Considering that these are scattered across the different islands, it would become very difficult, if not impossible, to perform the study based on these companies.

A first procedure was to withdraw financial institutions, because they have different accounting idiosyncrasies, when compared to other companies. As such, six banks and two insurers were excluded. Then, considering the availability of data, 57 companies were randomly selected, i.e. the equivalent of $71 \%$ of the total major contributors and $79 \%$ of the companies that could be considered in the study. As for the sources of information used, we collected data available in Report \& Accounts, obtained through information given by the Major Contributors Department of Direção Geral das Contrbuições e Impostos - DGCI.

Finally, we chose the years of 2011 and 2012 as periods of analysis, since the Ministry of Finance, considered the turnover (sales and services) declared and the taxes paid in these two economic exercises as criteria for defining the major Cape Verdean taxpayers.

To materialize the type of companies analysed, we separated companies of the studied sample by business sector, as follows in Table 1:

Table 1. Number of companies per business sector.

\begin{tabular}{ll}
\hline Business Sector & Number of Companies \\
\hline Commerce & 17 \\
Transport services & 2 \\
Construction & 11 \\
Industry & 10 \\
Tourism & 6 \\
Other services & 11 \\
\hline
\end{tabular}

Source: own elaboration

Table 2 Then Presents some economic and financial data on the sample, taking into as minimum, average and maximum values of each shown indicator.

Table 2. Economic and financial information of the sample (CVE).

\begin{tabular}{llll}
\hline Indicators & Minimum & Average & Maximum \\
\hline $\begin{array}{l}\text { Economic } \\
\text { - Turnover }\end{array}$ & 87.335 .903 & 1.913 .642 .456 & 17.217 .179 .000 \\
- Operating & -472.874 .000 & 264.446 .758 & 4.498 .500 .000 \\
income & & 175.849 .929 & 2.590 .891 .000 \\
- Net income & -823.446 .000 & & \\
Financial & & & \\
- Net assets & 69.223 .980 & 2.811 .103 .968 & 20.714 .984 .000 \\
- Equity & -909.942 .000 & 992.875 .899 & 8.683 .766 .000 \\
- Liabilities & 15.327 .736 & 1.818 .367 .577 & 18.077 .142 .000 \\
\hline
\end{tabular}

Source: own elaboration

As one can see, as far as dimension (turnover) is concerned, there is a large range of values ranging from 
87,335,903 CVE (847,158 EUR) to $17,217,179,000$ CVE (167,006,636 EUR).

As regards the results, on average, operating results is 2,565,133 EUR and net profit 1,705,744 EUR (meaning turnover of about $14 \%$ and $9 \%$ ).

As for net assets, the size of the companies in the sample confirms to be very diversified and it can be observed that its financing is mainly done through external capitals. However, equity has an average weight of $35 \%$ relatively to assets, which, when compared, for example to the Portuguese companies, it represents a good financial autonomy (according to Banco de Portugal these values are below 30\% in 2011 and 2012).

\subsubsection{Variables and Statistical Techniques}

For the analysis and validation of the research hypotheses, we used several statistical variables and techniques, which are described below.

H1: Impairment value is materially relevant and has impact on net income value and on assets value of Cape Verdean companies

To assess the materiality of the impairment registration in net income and assets, we analyse both income statement and balance sheet of the companies that constitute the sample and we compared the values in these Financial Statements with what they would have had, if impairment had not been recognized. To do so, we present the existing differences in absolute and relative values.

In addition, in order to test the degree of significance of registered impairment materiality, we held tests of differences in averages relative to the values of net results and assets, with and without impairment.

H2: Impairment value has an impact on income tax value of Cape Verdean companies.

To validate the second investigation hypothesis, we have used the multivariate linear regression with profit tax payable (ISL) as dependent variable, and the following independent variables, considered by referred research papers as being important to explain the fiscal results: Sales and service provision (VN), Operational costs without impairment (CO), Financial costs (CF) and, finally, Impairment recorded in each economic year (IMP).

In conclusion, we have reached the following regression model:

$$
\mathrm{ISL}=\beta 0+\beta 1(\mathrm{VN})+\beta 2(\mathrm{CO})+\beta 3(\mathrm{CF})+\beta 4(\mathrm{IMP})+\varepsilon
$$

\subsection{Results Analysis and Discussion}

After research methodology' characterization, we will carry out analysis and results discussion, supporting both defined objectives and the formulated test of the hypotheses.

\subsubsection{Impairment Materiality}

At this point, we intend to analyse the material importance of impairment recognition in the financial statements of Cape Verdean' major taxpayers. To do so, we will verify its relevance in companies' net income, and in companies' assets.

\section{Different types of Impairment recognition}

From the 57 companies of our sample, 37 (65\%) registered impairment or impairment reversals in the year 2012. For the Year 2011, 30 entities registered impairment, that is, 53\% of the companies studied.

Of those that registered impairment, both in 2012 and 2011, the data reveal a curious fact: of all existing asset impairment in the Cape Verdean accounting normative (receivables, non-current assets and inventories), more than $95 \%$ of the records are related to customers' receivables and inventories, the latter being called adjustments in inventories.

For instance, in 2012, of the 37 companies that registered impairment losses or reversals, there was a single case of impairment related to fixed tangible assets, in the amount of 24.467.027 CVE and a single record of impairment losses in intangible assets, in the amount of 500,000 CVE. In addition, we verified that, registered receivables' impairment losses are 3 times higher than registered inventories' impairment losses, in terms of frequency, and it values 31 times higher. This is because, 29 companies registered receivables' impairment losses, in the amount of 1.593.270.712 CVE and only 8, carried out inventories' impairment losses, value of 51.044.682 CVE. As regards impairment reversals' registration, we can see that, in 2012, 17 entities included values in their financial statements, representing 1.669.282.421 CVE.

Also, in 2011, registered receivables' impairment losses are higher than registered inventories' impairment losses. In terms of observations' frequency, they represent the double and in CVE value terms, are seven times higher.

One of the reasons that could explain, why most companies only register for these two impairment types, is the fact that the Cape Verdean tax system, only foresees straight deduction on these two categories. Take fixed tangible assets impairment deduction, for instance, which are called as extraordinary devaluations. The law is generic, often raising, debates between tax administrations and taxpayers.

It is also noteworthy that there are several companies that accounted for multiple impairment types and reversals (for example, in 2012 there are 15 entities that have simultaneous records).

For the Year 2011, the situation is identical, that is, of the 57 companies under study, 26 recorded receivables' impairment losses of 871.009.090 CVE, 13 registered inventories' impairment losses of 114.946.955 CVE, and there was only one record of impairment losses on intangible assets.

As to impairment level of disclosure, first, it should be recalled both international standards, as Cape Verdean ones, require companies to disclose the events and circumstances that led to the recognition or impairment loss' reversal. Thus, to better understand the circumstances that led to registered values, which, in many cases, are expressive, and to reject the hypothesis that it has been in accordance solely with the tax law, it was verified whether the entities' disclosures Information in the Balance sheet and Income statement' 
Annex (ABDR) justified the value of the registered impairment losses or reversals.

After the analysis, we can see that, from the 37 Companies that recorded impairment loss or reversed them in 2012, all $(100 \%)$ disclosed information about asset impairment in the ABDR, meeting the precepts emanating from international standards. However, regarding the justification of the origin of the recorded value, it was verified that only 15 entities $(41 \%)$, followed the stipulated in the said standard, showing the provenance of the values and the criteria used in their calculation.

The remaining 22 companies (59\%) simply registered the values, claiming, in many cases, that it is within the legal limit stipulated by the current tax law, (which is $4 \%$ on the amount of the existing credit), or even that it was deemed reasonable by management, considering the customer portfolio or inventories' level.

In summary, despite most of the assets being subject to impairment losses, according to the Cape Verdean' accounting standardization system, in the studied sample, consisting of 57 large companies, more than $95 \%$ of registered impairment or impairment reversals are related to receivables and inventories.

Impact analysis of impairment losses and impairment losses reversals on net income

Table 3 shows the impact of impairment' registration in companies' net income.

Table 3. Impairment or impairment reversals' Impact on companies'net income - Ni (CVE).

\begin{tabular}{|c|c|c|c|c|c|c|c|c|}
\hline \multirow{3}{*}{$\begin{array}{l}\text { Companies' } \\
\text { Total value }\end{array}$} & \multicolumn{4}{|l|}{ Year 2012} & \multicolumn{4}{|l|}{ Year 2011} \\
\hline & $\begin{array}{l}\text { Ni with } \\
\text { impairment }\end{array}$ & $\begin{array}{l}\text { Ni without } \\
\text { impairment }\end{array}$ & Variation & Impact \% & $\begin{array}{l}\text { Ni with } \\
\text { impairment }\end{array}$ & $\begin{array}{l}\text { Ni without } \\
\text { impairment }\end{array}$ & Variation & Impact \% \\
\hline & 8.166 .123 .338 & 9.711 .656 .382 & -1.545 .533 .044 & $-18,96$ & 5.909 .363 .651 & 6.897 .386 .296 & -988.022 .645 & $-16,72$ \\
\hline
\end{tabular}

As we can see, for the 37 companies that recorded impairment losses, or impairment reversals, in the year 2012, the net income total variation was negative, in the amount of 1.545.533.044 CVE.

In relation to the year 2011, also for all companies with impairment registration, the variation assumed negative values of 988.022.645 CVE.

Regarding the impact of the impairment losses, or impairment reversals' registration in the net income of 2012, in terms of relative values, it was negative in $18.96 \%$.

About the impact in 2011, for all companies, it assumed a negative percentage of $16.72 \%$.

Thus, by observing the data it can be suggested that, in fact, impairment losses, or impairment reversals did have impact on the net income of the analyzed companies. Thus, to verify whether the differences between the results, with and without impairment, were significant, we performed the test of averages differences for paired samples (because net income with and without impairment are related variables) and it was found that the significance level was less than 5\% $(\mathrm{P}=0.02862286$ in 2012 and $\mathrm{p}=0.029671136$ in 2011) showing whereas, if impairment losses, or impairment reversals hadn't been registered, net income were substantially different, both in 2012 and 2011. The statistics found were as follows.

Table 4. T Test of averages differences for paired samples (years 2012 and 2011).

\begin{tabular}{|c|c|c|c|c|}
\hline & $\begin{array}{l}\text { Ni with impairment and } \\
\text { reversals } 2012\end{array}$ & $\begin{array}{l}\text { Ni without impairment and } \\
\text { reversals } 2012\end{array}$ & $\begin{array}{l}\text { Ni with impairment } \\
\text { and reversals } 2011\end{array}$ & $\begin{array}{l}\text { Ni without impairment } \\
\text { and reversals } 2011\end{array}$ \\
\hline Mean & 220706036,2 & 262477199,5 & $159.712 .531,1$ & $186.415 .845,8$ \\
\hline Variance & $3,93163 \mathrm{E}+17$ & $3,81248 \mathrm{E}+17$ & $2,49088 \mathrm{E}+17$ & $2,3951 \mathrm{E}+17$ \\
\hline Observations & 37 & 37 & 37 & 37 \\
\hline Pearson Correlation & 0,984082231 & & 0,989658899 & \\
\hline Hypothesized Mean Difference & 0 & & 0 & \\
\hline df & 36 & & 36 & \\
\hline $\mathrm{P}(\mathrm{T}<=\mathrm{t})$ one-tail & 0,01431143 & & 0,014835568 & \\
\hline t Critical one-tail & 1,688297694 & & 1,688297694 & \\
\hline $\mathrm{P}(\mathrm{T}<=\mathrm{t})$ two-tail & 0,02862286 & & 0,029671136 & \\
\hline t Critical two-tail & 2,028093987 & & 2,028093987 & \\
\hline
\end{tabular}

Impact analysis of impairment losses and impairment losses reversals on current assets

As previously mentioned, only three cases of non-current assets' impairment were found, two in 2012 (one referring to tangible assets and the other to intangible) and a single case in 2011, referring to intangible asset, which is not representative. Thus, in the following table, we show evidences about variations and respective impacts of current asset impairment registration.

Table 5. Impairment or impairment reversals' Impact on companies' current assets - Ca (CVE).

\begin{tabular}{|c|c|c|c|c|c|c|c|c|}
\hline \multirow{3}{*}{$\begin{array}{l}\text { Companies' } \\
\text { Total value }\end{array}$} & \multirow{2}{*}{$\begin{array}{l}\text { Year } 2012 \\
\text { Ca with } \\
\text { impairment }\end{array}$} & \multicolumn{7}{|c|}{ Year 2011} \\
\hline & & $\begin{array}{l}\text { Ca without } \\
\text { impairment }\end{array}$ & Variation & Impact \% & $\begin{array}{l}\text { Ca with } \\
\text { impairment }\end{array}$ & $\begin{array}{l}\text { Ca without } \\
\text { impairment }\end{array}$ & Variation & Impact \% \\
\hline & 53.862 .989 .298 & 55.408 .522 .342 & -1.545 .533 .044 & $-2,87$ & 65.401 .668 .718 & 66.389 .691 .363 & -988.022 .645 & $-1,51$ \\
\hline
\end{tabular}


The observation of the previous table reveals that:

a) In 2012, the current asset impairment variation for the sample reaches the negative value of 1.545.533.044 CVE, having a weight of $2.87 \%$, which is a lower value, when compared to that verified in the net income analysis (table 3);

b) In the period of 2011, the total variation assumed, for all the selected entities, a negative value of 988.022.645 CVE, representing 1.51\% of the current assets.

Thus, the values suggest that current assets' impairment are less important in the formation of current assets' value. However, to verify its relevance, tests of averages differences for paired samples were again performed, between current assets values with and without impairment, and it was also found that the significance level was less than 5\% (p = 0.02862286 in 2012 and $p=0.029671136$ in 2011) which shows that, if there were no records of impairment and reversals, current assets were substantially different, both in 2012 and 2011. The table with the respective statistics presents as followed.

Table 6. T Test of averages differences for paired samples (years 2012 and 2011).

\begin{tabular}{|c|c|c|c|c|}
\hline & $\begin{array}{l}\text { Ca with impairment } \\
\text { and reversals } 2012\end{array}$ & $\begin{array}{l}\text { Ca without impairment and } \\
\text { reversals } 2012\end{array}$ & $\begin{array}{l}\text { Ca with impairment and } \\
\text { reversals } 2011\end{array}$ & $\begin{array}{l}\text { Ca without impairment } \\
\text { and reversals } 2011\end{array}$ \\
\hline Mean & $1.455 .756 .467,51$ & $1.497 .527 .630,86$ & 1.767 .612 .668 & 1.794 .315 .983 \\
\hline Variance & $4,79614 \mathrm{E}+18$ & $5,00509 \mathrm{E}+18$ & $9,25724 \mathrm{E}+18$ & $9,37491 \mathrm{E}+18$ \\
\hline Observations & 37 & 37 & 37 & 37 \\
\hline Pearson Correlation & 0,998960143 & & 0,999743768 & \\
\hline Hypothesized Mean Difference & 0 & & 0 & \\
\hline df & 36 & & 36 & \\
\hline $\mathrm{P}(\mathrm{T}<=\mathrm{t})$ one-tail & 0,01431143 & & 0,014835568 & \\
\hline t Critical one-tail & 1,688297694 & & 1,688297694 & \\
\hline $\mathrm{P}(\mathrm{T}<=\mathrm{t})$ two-tail & 0,02862286 & & 0,029671136 & \\
\hline t Critical two-tail & 2,028093987 & & 2,028093987 & \\
\hline
\end{tabular}

\subsubsection{Impairment Fiscal Impact}

Besides the model referred before in the research method, in order to verify the importance of impairment in income tax management, we developed a second one, also based on multivariate linear regression.

The first model was settled, where dependent variable is represented by companies' payable income tax and the explanatory variables are turnover, financial costs, operational costs without impairment and, of course, the annual value of registered impairment. We, therefore, expected that impairment was to be an important item in results' management for tax purposes, and we expected that there was a negative relationship with respect to payable income taxes, i.e., the lower the payable tax, the higher would be the values recorded as impairment. However, in order to make the study more robust, a second model was still carried out with impairment as dependent variable and turnover, financial costs, operational costs without impairment and payable income tax as explanatory variables. Thus, if impairment was recorded to decrease payable income taxes, it will tend to have a positive relationship with turnover evolution and a negative relationship with cost items, because the larger these are, the less need to register impairment to lower income taxes.

Finally, the developed regression models were subjected to the tests recommended by [22], to confirm their legitimacy:

a) Linearity of the relationship between model variables: No linear relationship was detected between the residues and the estimated values of the dependent variables;

b) Variance' Homogeneity: Heteroscedasticity was detected on both models. As such, the White test was performed to verify the significance of the variables with the robust standard deviations, and the results remained;

c) Errors' Normality: None of the models held normal distribution. However, in view of the size of the sample studied, more than 30 units can be considered as robust results [23];

d) Multicollinearity: The observation of Pearson's correlation coefficients, allowed us to verify that, in the final models, there was a strong relationship between the variable's turnover and operating costs without impairment. However, because the models remained robust and with the same type of results, by removing one of these variables, and because we wanted to show the relationship that turnover and operational costs without impairment had with the registered impairment, we chose to present the original models' results.

Table no. 7 shows the main statistics of the first model:

Table 7. Regression model with income tax (ISL) as dependent variable.

\begin{tabular}{ll}
\hline Dependent variables & Results \\
\hline & $-\mathrm{R}^{2}$ Adjusted $=0,782718 \rightarrow \mathrm{p}$-value $=0,000000^{*}$ \\
& - Financial costs $\rightarrow$ Coefficient $=1,186804 ; \mathrm{p}$ - \\
& value $=0,000000^{*}$ \\
& - Operating costs without impairment $\rightarrow$ \\
& Coefficient $=-0,191889 ; \mathrm{p}$-value $=0,000716^{*}$ \\
& - Impairment $\rightarrow$ Coefficient $=-0,667338 ; \mathrm{p}$-value \\
& $=0,00048^{*}$ \\
$\mathrm{ISL}$ & - Turnover $\rightarrow$ Coefficient $=0,200066 ; \mathrm{p}$-value $=$ \\
& $0,000378^{*}$ \\
\hline
\end{tabular}

*Significant for $\alpha<0,01$ 
Observing the statistics in the preceding table, the following considerations can be made:

a) The model is significant and holds a strong ability to explain the variable income tax, because $\mathrm{R}^{2}$ Adjusted is $78 \%$;

b) All variables have a relevant degree of significance (for $\alpha<0.01$ );

c) Expectably, turnover and operating costs have inverse relations with income tax. The turnover ratio is positive, and the operating costs ratio is negative. The financial costs have a positive relationship, which, although not expected, can be explained by the fact that companies with the highest capacity to create results (and pay taxes) also have a greater possibility of negotiating financing sources with banks;

d) Regarding impairment, besides being important to explain income tax, it has a negative relationship with this indicator, which may mean its registration in order to obtain lower tax obligations.

Next, we present the second model' statistics, performed with impairment as dependent variable.

Table 8. Regression model with impairment as dependent variable.

\begin{tabular}{ll}
\hline Dependent variables & Results \\
\hline & $-\mathrm{R}^{2}$ adjusted $=0,533761 \rightarrow \mathrm{p}$-value $=0,000000 *$ \\
& - Financial costs $\rightarrow$ Coefficient $=0,6979605 ; \mathrm{p}$ - \\
& value $=0,000009 *$ \\
& - Operating Costs without impairment $\rightarrow$ \\
& Coefficient $=-0,0984286 ; \mathrm{p}$-value $=0,05389 * *$ \\
& - ISL $\rightarrow$ Coefficient $=-0,480677 ; \mathrm{p}$-value $=$ \\
& $0,00048^{*}$ \\
& - Turnover $\rightarrow$ Coefficient $=0,113596 ; \mathrm{p}$-value $=$ \\
& $0,024743 * * *$ \\
\hline
\end{tabular}

*Significant for $\alpha<0,01$; ** Significant for $\alpha<0,1$; ** Significant for $\alpha<0,05$

As for this model, it also allows to observe some important relationships:

a) It is equally significant and explains about $54 \%$ of impairment' formation;

b) Although all the variables are relevant to explain impairment' registration, those that have a higher degree of significance are financial costs and income tax. The financial costs ratio is positive, what may be associated with the fact that the most indebtedness companies are those who also have more difficulties to receive debts from their customers; the income tax ratio is negative and, as previously mentioned, it may be related to impairment registration to decrease companies' amount of payable income tax;

c) Turnover has a positive relationship with dependent variables, probably because, as the level of income increases, it also rises impairment' recording to reduce income taxes;

d) Operational costs have a negative relationship with impairment, which can show that the higher the activity costs, the lower the need for impairment registration to decrease income taxes;

e) Finally, it is noteworthy that, after performing the
White Test to verify variables' significance with robust standard deviations, although the coefficients' signs have remained the same, only income taxes and financial costs maintain a statistically significant relationship with total impairment. However, it is also noteworthy that, by performing the model without operating costs without imparity (variable that has a very strong relationship with turnover), all variables reveal a significant relationship with impairment, validating its importance in companies' tax management.

Thus, it seems that there is significant evidence that impairment may be important in tax management of major tax payers' of Cape Verdean economy.

\section{Conclusion}

The main purpose of this research was to know the level of materiality of impairment losses registered by Cape Verdean companies and to analyze their tax impact. To achieve the proposed objective, we used the Report \& Accounts of years 2012 and 2011 of 57 large companies of Cape Verde. The selection of such economic periods was since those were the reference years for defining the country's major taxpayers, as well as for the accounting standards.

The study shows that of the 57 companies that compose the sample, $65 \%$ (37 entities) and 53\% (30 entities) recorded impairment losses or impairment reversals in 2012 and 2011, respectively. Despite most of the assets being subject to impairment losses and Cape Verdean' accounting regulations foreseeing multiple types for its recognition, it appears that, both in 2012 and 2011, more than $95 \%$ of the records are related to receivables and inventories impairment losses or impairment reversals, and the registration of the former was always higher than the second. This fact may be explained by the sample's composition, where most of the companies' activity is to provide services. Likewise, it is noteworthy that the tax law directly allows only the deduction of these two impairments, which may also justify its registration.

As regards the hypotheses raised, in order to measure the significance level of the materiality of the recorded imparities, tests of averages differences were performed, relatively to net assets and net income values, with and without impairment.

The tests of averages differences for paired samples confirmed the materiality of the records of the impairment losses or impairment reversals, presenting values below a significance level of $5 \%$, which demonstrates the relevance of the accounts, both in 2012 and 2011.

Regarding the second hypothesis, two multivariate linear regression models were performed. In first one, income tax was defined as a dependent variable and turnover, financial costs, operational costs without impairment and impairment as independent variables; In the second one, impairment represented the dependent variable and, turnover, financial costs, operational costs without impairment and income tax 
were the explanatory variables.

The first model's results show that there is a significant and negative relationship between impairment and income tax, which means that Cape Verde companies can use this accounting record to pay less taxes. This is still confirmed by the second model, in which the results show that turnover has a positive relationship with registered impairment, which may express that, as the level of income increases, it also enhances the concern about impairment, as a way of reducing income taxes.

About the main limitations of this investigation, the fact that, in a total of 57 companies analysed, 20 did not have any impairment, which could limit generalisation. Another limitation found was the informality of Cape Verde's economy, allied to its archipelago condition, which limits the potential sample of companies to study.

In Terms of future research lines, it is important to carry out a study with the latest data from recent years, to verify impairment records' evolution on the first 2 years of the standards' application, and possible out coming differences with current study.

\section{References}

[1] Grenha, C., Cravo, D., Baptista \& L., Pontes, S, (2009). Anotações ao sistema de Normalização Contabilística. CTOC - Camara dos técnicos Oficiais de contas.

[2] Decreto - Lei No $5 / 2008$ de 4 de Fevereiro - Adoção do SNCRF, Cabo Verde.

[3] Cunha, A., Correia, A., \& Oliveira, P. (2010). Justo valor ou imparidade, em contexto de crise? Revista contabilidade e Empresas. Vida Económica, $5-2^{\mathrm{a}}$ Série, 17-25.

[4] Silva, N. (2012). Julgamentos profissionais no SNC e seus feitos em sede de IRC. Unpublished dissertation. Universidade de Aveiro.

[5] Gonçalves, C. \& Fernandes, J. (2009). Sistema de Normalização Contabilística proposto pela CNC enquanto referencial normativo em Cabo Verde. TOC 111.

[6] Martins, A. (2010). Justo Valor e Imparidade em Activos Fixos Tangiveis e Intangiveis - Aspetos Financeiros, Contabilísticos e Fiscais. Coimbra: Almedina.

[7] Rodrigues, I. (2009). O conceito de Imparidade e sua evolução Histórica - A aplicabilidade da NRF 17. Mindelo: Instituto Superior de Ciências Económicas e Empresariais.

[8] Lucena, W. G., Fernandes, M., França, J. \& Capelletto, L. R. (2009). Estudo do nivel de evidenciação do impairment pelos bancos brasileiros: uma aplicação da análise do conteúdo com base nas notas explicativas. Revista Contabilidade e Controladoria, 1, 45-60.
[9] Fernandes, I. (2011). Imparidade em Activos Fixos Tangiveis. Unpublished dissertation. Universidade de Porto.

[10] Rafael, M. (2012). Imparidade de Ativos Fixos Tangíveis aspetos contabilísticos, fiscais e de Auditoria. Unpublished dissertation. Instituto Politécnico de Porto.

[11] Muhammad, K. (2012). The effect of Asset Impairment (IAS 36) in Improving the Quality of Accounting Information According to Users' Perspective: Evidence from Jordan. Unpublished Phd dissertation. Durham University.

[12] Carvalho, A., Rodrigues, A., \& Ferreira, C. (2013). A Relevância das Perdas por Imparidade do Goodwill nos oito anos de aplicação das IAS/IFRS em Portugal. Lisboa: XIV Congresso Internacional de Contabilidade e Auditoria.

[13] Laskaridou, E. \& Athanasious, V. (2013). Detecting Asset Impairment Management: Some Evidence from Food and Beverage Listed Companies. Procedia Technology, 8, 493497.

[14] Sooriyakumaran, L \& Velnampy, T. (2013). Disclosures and impacts of impairment of non-current assets in the financial statements: A study on listed manufacturing companies in Colombo Stock Exchange (CSE) in Sri Lanka. Merit Research Journal of Accounting, Auditing, Economics and Finance, $1(6), 122-133$.

[15] Arachi, G \& Bucci, V. (2013). Do taxes affect firms asset write-downs? Evidence from discretionary write-downs of equity investments in Italy. Working Papers EC0002, University of Salento.

[16] Edwards, A. (2018). The Deferred Tax Asset Valuation Allowance and Firm Creditworthiness. The Journal of the American Taxation Association: Spring 2018, 40 (1), 57-80.

[17] Gunn, J., Khurana I. \& Stein, S. (2018). Determinants and consequences of timely asset impairments during the financial crisis. Journal of Business, Finance \& Accounting, 45 (1-2), 3-39.

[18] Gordon, E. \& Hsu, H. (2018). Tangible Long-Lived Asset Impairments and Future Operating Cash Flows under U.S. GAAP and IFRS. The Accounting Review, 93 (1), 187-211.

[19] Stein, S (2019). Auditor Industry Specialization and Accounting Estimates: Evidence from Asset Impairments. AUDITING: A Journal of Practice \& Theory, 38 (2), 207-234.

[20] Banco Mundial (2014). Cabo Verde Aspetos gerais. Retrieved from: http://www.worldbank.org/pt/country/caboverde/overview. Acesso em 15/04/2016.

[21] Portaria n ${ }^{\circ} 55 / 2013$ de 14 de Dezembro, Cabo verde.

[22] Pinto, J., \& Curto, J. (1999). Estatística para economia e gestão: instrumentos de apoio à tomada de decisão. Lisboa: Edições Sílabo.

[23] Moutinho, L. \& Hutcheson, G. (2008) Statistical Modelling for Management. London: SAGE. 